ARTICLE

https://doi.org/10.1038/s41467-019-11726-4

\title{
Nucleosome and ubiquitin position Set2 to methylate $\mathrm{H} 3 \mathrm{~K} 36$
}

\author{
Silvija Bilokapic (i) ${ }^{1} \&$ Mario Halic (i) ${ }^{1}$
}

Histone H3 lysine 36 methylation (H3K36me) is a conserved histone modification deposited by the Set2 methyltransferases. Recent findings show that over-expression or mutation of Set2 enzymes promotes cancer progression, however, mechanisms of H3K36me are poorly understood. Set2 enzymes show spurious activity on histones and histone tails, and it is unknown how they obtain specificity to methylate H3K36 on the nucleosome. In this study, we present $3.8 \AA$ cryo-EM structure of Set2 bound to the mimic of $\mathrm{H} 2 \mathrm{~B}$ ubiquitinated nucleosome. Our structure shows that Set2 makes extensive interactions with the $H 3 \alpha N$, the $\mathrm{H} 3$ tail, the H2A C-terminal tail and stabilizes DNA in the unwrapped conformation, which positions Set2 to specifically methylate H3K36. Moreover, we show that ubiquitin contributes to Set2 positioning on the nucleosome and stimulates the methyltransferase activity. Notably, our structure uncovers interfaces that can be targeted by small molecules for development of future cancer therapies.

\footnotetext{
${ }^{1}$ Department of Structural Biology, St. Jude Children's Research Hospital, 263 Danny Thomas Place, Memphis, TN 38105, USA. Correspondence and requests for materials should be addressed to S.B. (email: Silvija.Bilokapic@stjude.org) or to M.H. (email: Mario.Halic@stjude.org)
} 
istone modifications are a key player in maintaining genome stability, chromosome segregation, and genome expression ${ }^{1}$. One of the essential histone modifications, histone $\mathrm{H} 3$ lysine 36 methylation $(\mathrm{H} 3 \mathrm{~K} 36 \mathrm{me})$ is deposited by the Set2 methyltransferase onto the $\mathrm{H} 3$ tail and is conserved from yeast to humans ${ }^{2,3}$. Set 2 is recruited by phosphorylated Cterminal domain of RNA Polymerase 2 during transcription and catalyzes $\mathrm{H} 3 \mathrm{~K} 36$ methylation over gene bodies $^{4-9}$. In addition to Set2, RNA Polymerase 2 elongation complex recruits Bre1/Rad6 that ubiquitinate $\mathrm{H} 2 \mathrm{~B} \mathrm{~K} 120^{10,11}$, indicating possible interplay between these two histone modifications. Both, H3K36me and H2B K120 ubiquitination are enriched over gene bodies ${ }^{12}$. $\mathrm{H} 3 \mathrm{~K} 36 \mathrm{me}$ recruits Rpd3S histone deacetylase complex to restore a repressed chromatin state behind the elongating polymerase ${ }^{13,14}$. Although deposited by the transcription machinery, H3K36me seems to be a silencing mark that prevents initiation of cryptic transcription within gene bodies ${ }^{2,15-17}$. Recent data show that Set2 and H3K36me are also involved in DNA damage repair ${ }^{18-20}$, regulation of pre-mRNA splicing ${ }^{21,22}$, chromatin condensation ${ }^{23}$, and histone exchange ${ }^{24,25}$.

In animals, Set 2 family enzymes are essential for maintenance of cell identity ${ }^{26,27}$ and are mutated in many patients with clear cell renal cell carcinoma, acute leukemias, bladder cancer, and glioblastoma ${ }^{28-30}$. Recently, mutation of $\mathrm{H} 3.3 \mathrm{~K} 36$ to methionine has been found in chondroblastomas, head and neck squamous cell carcinoma, and colorectal cancer ${ }^{31-36}$. H3.3K36M mutation traps SETD2 methyltransferase on the substrate which results in genome-wide loss of H3K36 methylation and tumor formation ${ }^{33,35}$. Set2 family enzymes are overexpressed in multiple myeloma, neuroblastoma, bladder and breast cancers, and correlate with poor prognosis ${ }^{3,37-40}$. These findings show that overexpression or mutation of Set 2 enzymes or H3K36 promote cancer progression.

Although Set 2 involvement in essential cellular processes is well described, mechanisms of Set 2 mediated H3K36 methylation are poorly understood. In this study, we present $3.8 \AA$ cryo-EM structure of Set 2 bound to the mimic of $\mathrm{H} 2 \mathrm{~B}$ ubiquitinated nucleosome core particle $(\mathrm{NCP})^{41}$. Our structure shows that Set2 makes extensive interactions with $\mathrm{H} 3 \propto \mathrm{N}, \mathrm{H} 3$ tail, H2A Cterminal tail, and stabilizes DNA in an unwrapped conformation $^{42}$. These interactions with the nucleosome are required for the specificity toward H3K36 methylation. Moreover, we show that the AWS domain of Set 2 interacts with ubiquitin which promotes H3K36 methylation. Our structure reveals the interface between nucleosome and Set2, which is a potential drug target for cancer treatments.

\section{Results}

Cryo-EM structure of Set2 bound to nucleosome. Histone H3K36me3 and H2BK120 ubiquitination are hallmarks of active chromatin. To visualize the mechanism of H3K36 methylation, we assembled the complex of Set 2 and the mimic of H2B ubiquitinated nucleosome ${ }^{43}$, the substrate of Set2 (Supplementary Fig. 1a-d). To stabilize the complex we have introduced H3K36M mutation ${ }^{44,45}$, recently identified in childhood cancers (Supplementary Fig. 1e). In the electron micrographs the complex is present in various orientations and in a subset of 2D class averages an additional density was bound to the NCP (Supplementary Fig. 1f, g). In initial $3 \mathrm{D}$ reconstruction, with overall resolution at $3.4 \AA$, a noisy density representing Set 2 domain was present near the DNA entry/exit site of the nucleosome (Supplementary Fig. 2). $\sim 14 \%$ of the initial particles contained Set2 and further focused classification improved the Set2 density yielding a map at $3.8 \AA$ (Set2:NCP) (Table 1, Fig. 1a and Supplementary Fig. 2, 3a). Remarkably, not only NCP, but also Set2 is
Table 1 Cryo-EM data collection, refinement, and validation statistics

$\begin{array}{lll}\text { Set2_NCP } & \text { Set2_Ub_NCP } & \text { NCP EMD- } \\ \text { EMD-0559 } & \text { EMD-20517 } & \text { 20516 PDB } \\ \text { PDB } & \text { PDB ID 6PX3 } & \text { ID 6PX1 } \\ \text { ID 6NZO } & & \end{array}$

Data collection and processing

Magnification

Voltage (kV)

Electron exposure 75

$\left(\mathrm{e}-/ \AA^{2}\right)$

Defocus range $(\mu \mathrm{m})$

Pixel size $(\AA)$

Symmetry imposed

Initial particle

images (no.)

Final particle

images (no.)

Map resolution $(\AA)$

FSC threshold

Map resolution

range $(\AA)$

Refinement

Initial model used 6FQ5

Model resolution $(\AA) \quad 3.8$

FSC threshold

Model resolution

range $(\AA)$

Map sharpening $B$

factor $\left(\AA^{2}\right)$

Model composition

Nonhydrogen atoms Protein residues Ligands

$B$ factors $\left(\AA^{2}\right)$

Protein

Ligand

300

300

300

$75-75$

75

-0.7 to $-3.0-0.7$ to -3.0

$1.04 \quad 1.04$

C1 C1

$\sim 1,500,000 \sim 1,500,000$

1.04

1.04
$\mathrm{C} 2$

$\sim 1,500,000$

66,000

50,000

210,000

3.8

4.1

3.3

$3.6-5.0$

3.8-8.0

3.1-3.5

6FQ5

4.1

6FQ5

3.3

235-3.8

235-4.1

235-3.3

$-100$

0

$-120$

R.m.s. deviations Bond lengths $(\AA)$

Bond angles $\left({ }^{\circ}\right)$

13740

14336

11939

990

1060

752

3

3

0

55.16

297.17

41.58

129.02

397.28

0.008

0.929

0.006

Validation

MolProbity score 1.4

Clashscore $\quad 3.44$

Poor rotamers (\%) 0.12

Ramachandran plot

Favored (\%)

Allowed (\%)

Disallowed (\%)

95.11

4.89

0.0

1.55

4.62

0.45

0.45

95.45

4.55

0.0

2.31

0

98.10

1.90

0.0

resolved to high resolution allowing us to describe interactions in molecular details. In this map, resolution of Set 2 on the nucleosome proximal side is similar to the nucleosome with many side chains resolved, whereas on the nucleosome distal side the resolution drops to $\sim 4-5 \AA$ (Supplementary Fig. 3b-c). Although we used full-length Set 2 for the complex formation, in our map we observe only densities for the AWS and the SET domains (Supplementary Fig. 3d). This is in agreement with previous data showing that the SET domain is sufficient to bind nucleosome and to methylate $\mathrm{H} 3 \mathrm{~K} 36^{6,46,47}$. We refined the cryo-EM model of the nucleosome assembled on $601 \mathrm{DNA}^{42,48}$ (PDB:6FQ5) and the Set2 model (PDB:5V21, 5JJY) 44,45 and observed several changes in their structures when assembled in the complex (Fig. 1b and Supplementary Fig. 3e).

Our cryo-EM structure shows that Set2 stabilizes the unwrapped state of the nucleosome, which resembles the Class 2 state we have previously observed ${ }^{42}$ (Fig. 1a, b). The DNA 
a

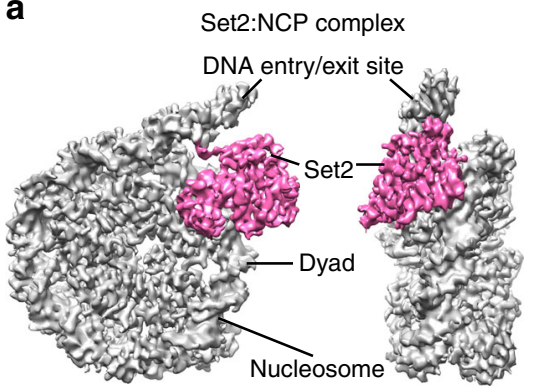

b

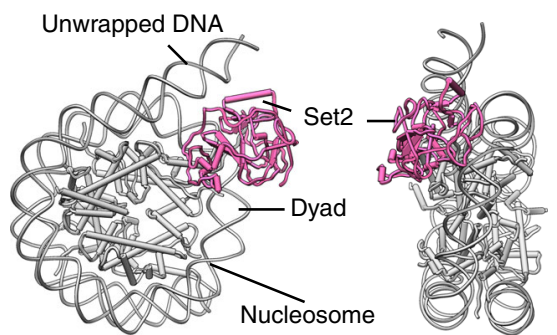

Fig. 1 Cryo EM structure of Set2 methyltransferase bound to the NCP. a Cryo-EM map of Set2 bound to NCP at $3.8 \AA$. NCP is shown in gray and Set2 in pink. Set2 stabilizes NCP with the unwrapped DNA. b Model for cryo-EM map of the Set2 bound to NCP. NCP is shown in gray and Set2 in pink

a

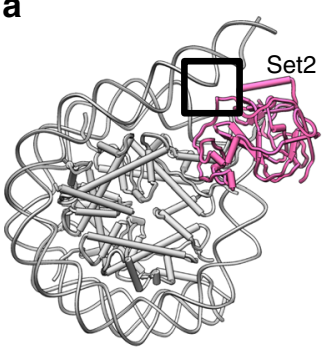

C

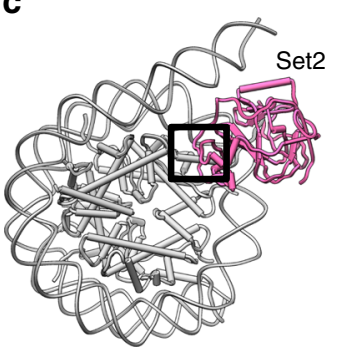

e

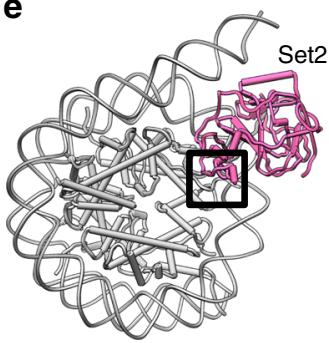

DNA (SHL 5.5)
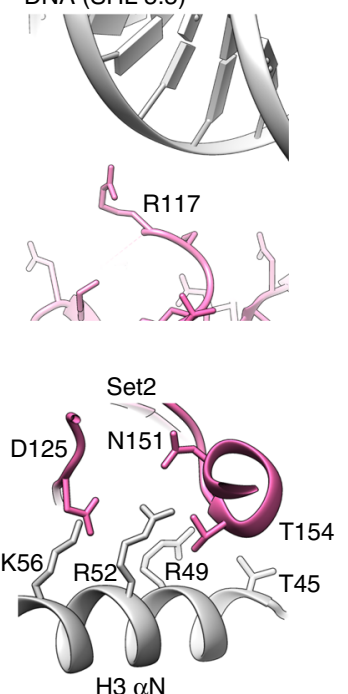

$\mathrm{H} 3 \alpha \mathrm{N}$

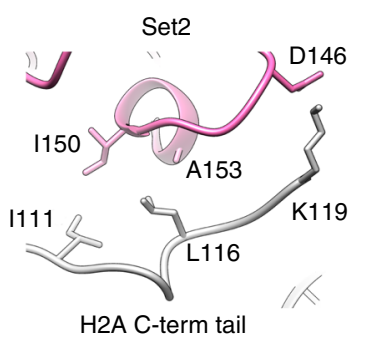

b

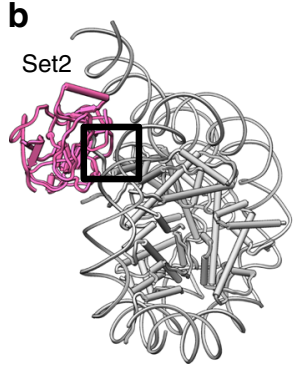

d

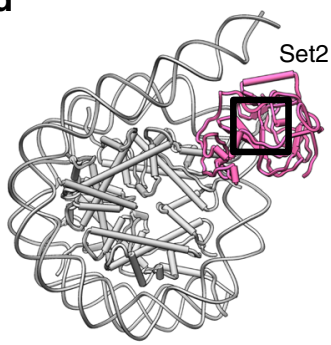

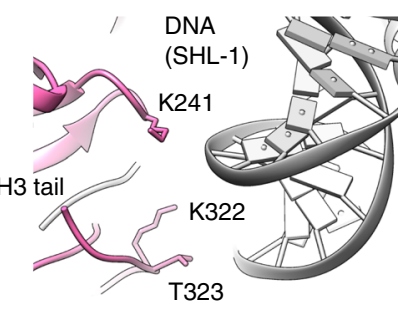

H3 N-term tail Set2

Fig. 2 Molecular interactions between Set2 and NCP. Global location of the depicted interaction between Set2 and the nucleosome is shown on the left and close up on the right. a Set2 residue R117 binds the backbone of the unwrapped DNA at SHL 5.5. b Set2 residues K241, K322, and T323 bind the backbone of the DNA at SHL-1. c Set2 binds H3 $\alpha$ N. Set2 residues D125, N151, and T154 bind the H3 K56, R52, R49 and T45. d The H3 tail makes extensive interactions with Set2 and the DNA. H3 R40 and K37 bind the DNA at SHL-1. H3 Y41 and H39 interact with Set2 residues K155, K268, and N295. Set2 residue K269 interacts with the main chain of H39. e Set2 binds the H2A C-terminal tail. Set2 D146 makes charged interaction with H2A K119. Set2 residues 1150 and $A 153$ make hydrophobic interactions with the H2A residues 1111 and L116, respectively

unwrapping is required for Set2 to bind $\mathrm{H} 3 \mathrm{~K} 36$ that is located close to the DNA entry/exit site of the nucleosome. The conserved positively charged Set2 residue R117 binds the backbone of the unwrapped DNA at SHL 5.5 and stabilizes the open conformation (Fig. 2a and Supplementary Fig. 3e, f). Moreover, Set2 makes a set of electrostatic interactions with the backbone of the DNA near the dyad (Fig. 2b and Supplementary Fig. 3g). This interaction with the DNA at SHL-1 rearranges the Set2 Post-Set domain when compared with the crystal structure ${ }^{44}$ (Supplementary Fig. 3h).

In addition to the DNA, Set2 makes multiple interaction with histones $\mathrm{H} 3$ and $\mathrm{H} 2 \mathrm{~A}$ that position Set 2 catalytic domain for functional interaction with $\mathrm{H} 3 \mathrm{~K} 36$. Set2 residues D125 and N151 interact with positively charged residues K56 and R52, while H3 R49 and T45 face toward the Set2 A153 and T154 (Fig. 2c). These $\mathrm{H} 3 \mathrm{aN}$ residues organize the last $13 \mathrm{bp}$ of DNA in the nucleosome, but as DNA is unwrapped in the complex, the side chains adopt different conformation and bind Set2 (Supplementary Fig. 3c, i). Set2 interaction further extends to the H3 tail where $\mathrm{H} 3 \mathrm{Y} 41$ binds into the pocket formed by $\mathrm{H} 3$ residues $\mathrm{R} 49$, V46, and T45, and by Set 2 residues K155 and K269. Y41 aromatic ring packs against invariant Set2 K269, which together with N295 and N297 also coordinates H3 H39 (Fig. 2d and Supplementary Fig. 4a). When $\mathrm{H} 3$ tail is bound to Set2, positively charged 

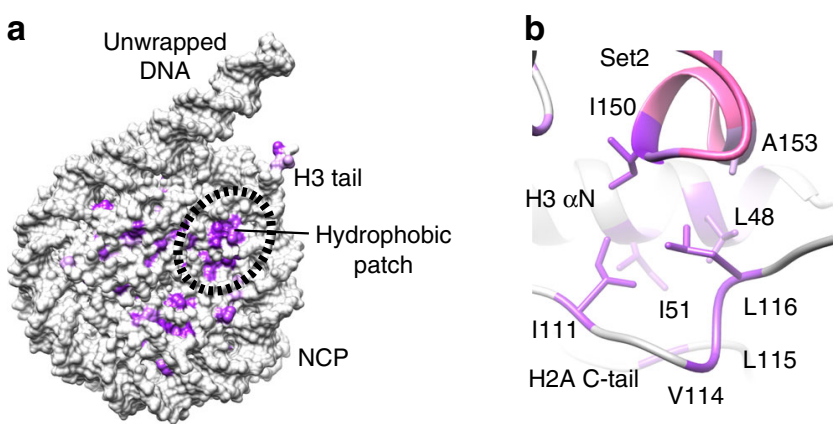

C
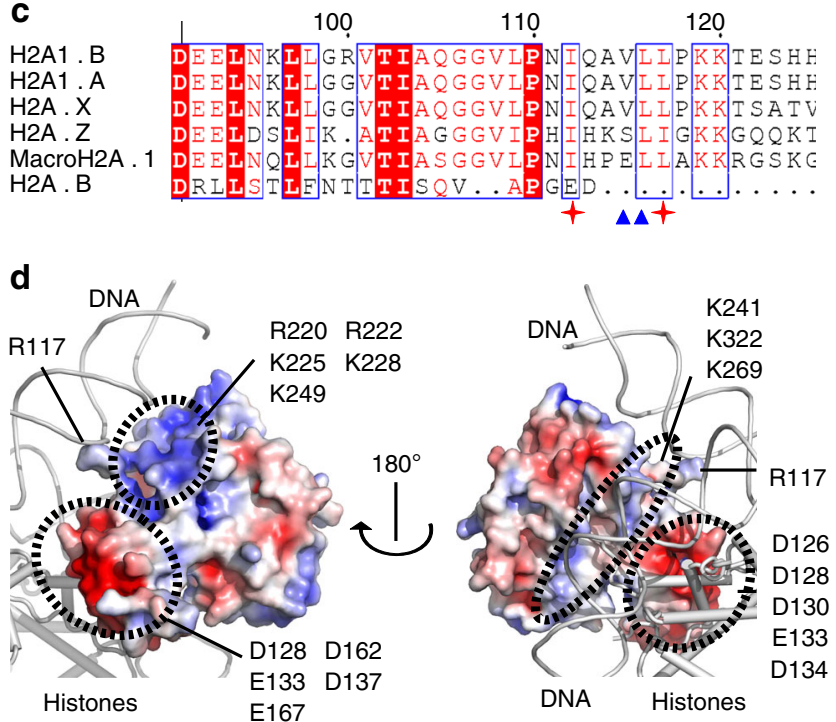

Fig. 3 Set2 makes hydrophobic and charged interactions with NCP. a Hydrophobic residues on the surface of NCP are shown in violet. Black dashed circle marks hydrophobic patch on the NCP. $\mathbf{b}$ Hydrophobic patch of NCP is formed by $\mathrm{H} 3 \alpha \mathrm{N}$ residues $\mathrm{I} 1$ and $\mathrm{L} 48$ and H2A C-terminal tail residues I111, L115, and L116. Set2 residues 1150 and A153 bind the hydrophobic patch of NCP. c Sequence alignment of the C-terminal tail of the representative $\mathrm{H} 2 \mathrm{~A}$ histone variants. Conserved residues are highlighted in red. The position of 1111 and L116, residues that build hydrophobic pocket on the nucleosomal surface, are labeled with the red cross. V114 and L115 that position H2A C-terminal tail are marked with blue triangle. Residues important for the interactions with Set2 enzyme are not conserved in H2A.B. The alignment was generated with the ESPript server (http://espript.ibcp.fr) ${ }^{83}$. d Electrostatic surface potential of Set2.

Set2 surface facing DNA is predominately positively charged (blue), whereas Set 2 residues facing positively charged histones are mainly negatively charged (red)

residues $\mathrm{H} 3 \mathrm{R} 40$ and $\mathrm{K} 37$ face toward the DNA and contribute to position the $\mathrm{H} 3$ tail for the interaction with Set2 (Fig. 2d). Whereas H3 M36(K36) is positioned in a similar way to Set2 crystal structures $^{44,45}$, the $\mathrm{H} 3$ residues following the H3 P38 take a different path in our structure and bind both Set 2 and the nucleosomal DNA (Supplementary Fig. 4b, c). It has been suggested that P38 plays a role in the H3K36 methylation ${ }^{49}$ and our data show that the $\mathrm{H} 3$ tail kinks at the P38 to accommodate restrains provided by the nucleosome and to allow for Set2 binding.

Beside the interactions with $\mathrm{H} 3$, Set2 residue D146 makes an interaction with $\mathrm{K} 119$ in the H2A C-terminal tail and rearranges the tail (Fig. 2e and Supplementary Fig. 4d). Moreover, Set2 residues $\mathrm{I} 150$ and A153 make hydrophobic interactions with the $\mathrm{H} 2 \mathrm{~A}$ C-terminal tail $\mathrm{I} 111$ and L116, and $\mathrm{H} 3 \mathrm{aN}$ residues $\mathrm{I} 51$ and
L48 (Fig. 2e). In addition to prevailing charged interactions, our structure shows that Set2 binds hydrophobic patch of the nucleosome formed by the H2A C-terminal tail and the $\mathrm{H} 3 \alpha \mathrm{N}$ (Fig. 3a, b and Supplementary Fig. 4e). This hydrophobic patch, utilized by Set 2 is likely to be another hot spot for interactions with the nucleosome, similarly to the acidic patch ${ }^{50}$. Biochemical data have shown that Sgo1, COC complex, AKT protein kinase B, ISWI remodelers, and many other complexes require residues in the hydrophobic patch for nucleosome binding and the activity ${ }^{51-53}$ and might bind the nucleosome in a similar way to Set2. Notably, we do not observe Set2 SET domain binding to the acidic patch.

We observed that histone $\mathrm{H} 2 \mathrm{~A}$ variant $\mathrm{H} 2 \mathrm{~A} . \mathrm{B}$ does not have the hydrophobic residues that interact with Set2 (Fig. $3 c$ and Supplementary Fig. 5a, b). H2A.B histone variant is associated with active transcription 54,55 , however, in contrast to the canonical $\mathrm{H} 2 \mathrm{~A}$, in vivo data show that H2A.B containing nucleosomes are not methylated on $\mathrm{H} 3 \mathrm{~K} 36^{55}$. Residues essential for Set2 binding are not present in H2A.B nucleosomes and our results explain why these nucleosomes do not have H3K36me, although found in regions that are methylated on H3K36. Our data provide insight into the modulation of chromatin landscape by interplay between histone post-translational modifications and histone variants.

In our structure Set2 makes extensive charged and hydrophobic interactions with the DNA and the histones. The structure shows that Set 2 residues facing the DNA are predominately positively charged, whereas, the residues that are facing the positively charged histones are negatively charged (Fig. 3d). Notably, the residues interacting with the nucleosome show higher degree of conservation (Supplementary Fig. 5c).

H2BK120 ubiquitination stimulates Set2 activity. Set2 is recruited to chromatin by RNA Polymerase II elongation complex, which also recruits Bre1 E3 ligase that ubiquitinates H2B. Moreover, recent in vivo data reveal a link between $\mathrm{H} 2 \mathrm{~B}$ ubiquitination and $\mathrm{H} 3 \mathrm{~K} 36 \mathrm{me} \mathrm{e}^{41}$. Therefore, we have postulated that H2B ubiquitination might stabilize the Set2:NCP complex for cryo-EM studies. In the Set 2 map, the density for ubiquitin is visible only at low contour level, indicating local flexibility (Supplementary Fig. 6a, b). We have used focused classification to improve the ubiquitin density, which yielded maps with no visible ubiquitin, flexible ubiquitin, and defined ubiquitin (Supplementary Fig. 6c). In all maps, Set2 was in the same conformation, indicating that $\mathrm{H} 3 \mathrm{~K} 36 \mathrm{M}$ mutation is the primarily stabilizing factor in our construct. In the cryo-EM map (Set2:Ub_NCP) at $4.1 \AA$ ubiquitin is resolved to $5-8 \AA$ and secondary structure elements are visible permitting us to fit the ubiquitin crystal structure (PDB:1UBQ) (Fig. 4a and Supplementary Fig. 6d-g). In our complex, Set2 residues 129-135 of the AWS domain come to proximity to residues $63-67$ of the C-terminal $\beta$-strand of ubiquitin (Fig. 4b and Supplementary Fig. 6e).

Although this interaction is not well defined in the structure, our data suggest that ubiquitin helps positioning Set 2 on the nucleosome. Therefore, we have generated ubiquitinated nucleosomes by ligating ubiquitin to H2B K12056 (Supplementary Fig. 7a-f) and by fusing ubiquitin to the H2A N-terminus (R17), which is an efficient mimic of naturally occurring H2BK120 ubiquitination $^{43,57}$ (Supplementary Fig. 1b-d and Supplementary Fig. 7g). Our data show that Set2 activity is higher on both mimics of H2B K120 ubiquitinated nucleosomes when compared with the unmodified nucleosomes, indicating that ubiquitin stimulates the activity (Fig. 4c, d and Supplementary Fig. 8a, b). Further, we added Set 2 to an equimolar mix of unmodified and $\mathrm{H} 2 \mathrm{~B}$ ubiquitinated nucleosomes, and observed that Set2 
a Set2:Ub_NCP complex

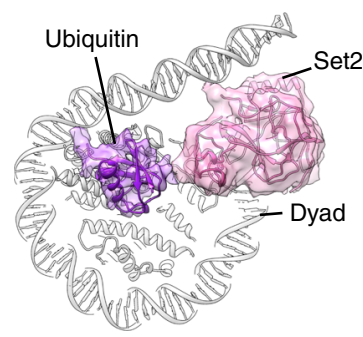

b

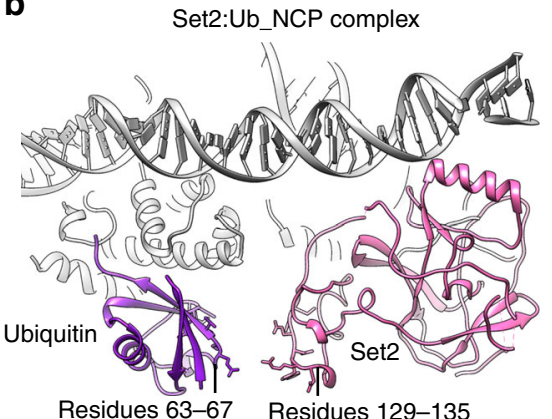

e

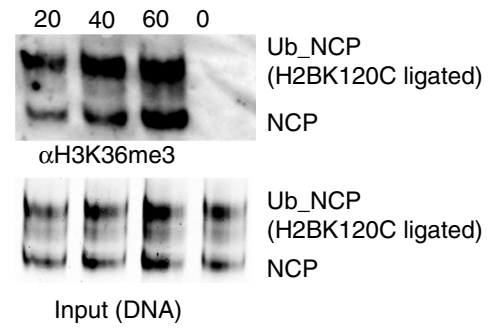

C

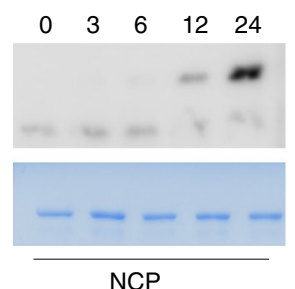

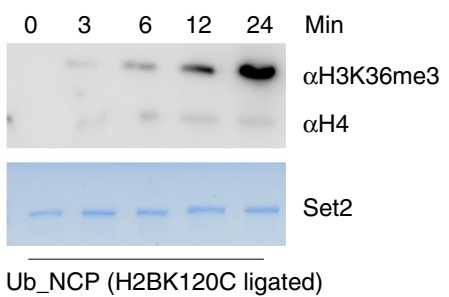

d

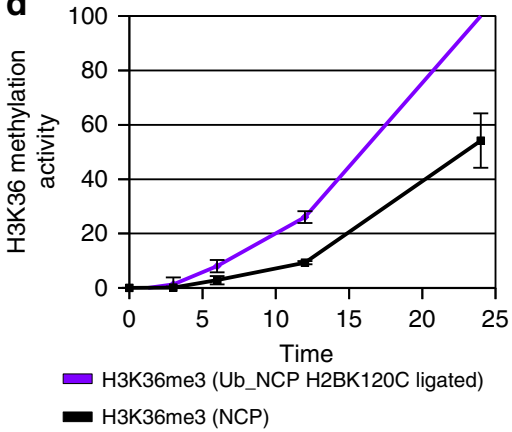

Fig. 4 Ubiquitin binds Set2 and stimulates Set2 H3K36me3 activity. a Cryo-EM map resolved to $4.1 \AA$ showing a subset of particles with defined density for ubiquitin, which interacts with Set2. Ubiquitin density and model are shown in violet. Set2 density and model are shown in pink. NCP is shown as model in gray. b The model showing overall interaction between Set2 and ubiquitin. Ubiquitin residues 63-67 come to close proximity to Set2 AWS domain (residues 129-135). c Set2 methyltransferase assay with the unmodified and the H2BK120C ubiquitinated nucleosomes. In presence of H2BK120C ubiquitin, Set2 shows increased H3K36me3 when compared with unmodified nucleosome. d Quantification of Set2 methyltransferase activity assay from (c). Error bars show standard error of three independent replicates. e Set2 methyltransferase competition assay with equimolar amounts of both the unmodified and the H2BK120C ubiquitinated nucleosomes. The nucleosomes were separated on the native gel: sample stained with SybrGold is shown in the lower panel and tri-methylation activity detected with $\mathrm{H} 3 \mathrm{~K} 36 \mathrm{me} 3$ antibody in the upper panel. Upper band is the H2BK12OC ubiquitinated nucleosomes and the lower band are the unmodified nucleosomes. Source data are provided as a Source Data file

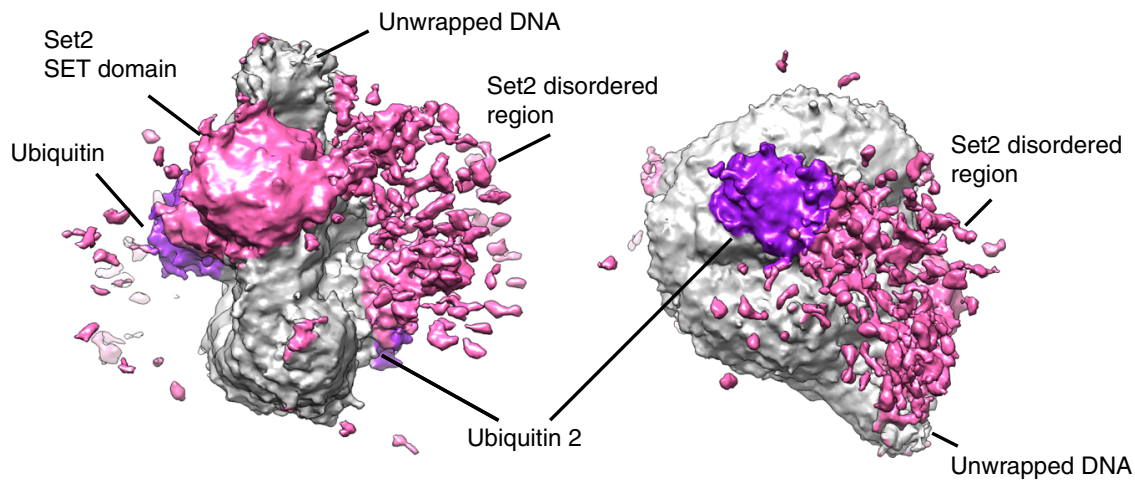

Fig. 5 Set2 auxiliary regions bind the nucleosome. Cryo-EM map resolved to $4.2 \AA$ showing a subset of particles with the noisy density next to the nucleosome. The noisy density is spanning from the Set2 SET domain and the unwrapped DNA to the second ubiquitin on the opposite side of the nucleosome. This density is generated by auxiliary Set2 domains and disordered regions. Ubiquitin is shown in violet, Set2 in pink, and NCP in gray

preferably methylates $\mathrm{H} 2 \mathrm{~B}$ ubiquitinated nucleosomes (Fig. 4e). Although H2B K120 ubiquitin increases Set2 activity, it does not increase Set2 binding to the nucleosome, suggesting that ubiquitin rather promotes positioning of the Set2 active site over the substrate (Supplementary Fig. 8c). In conclusion, our data show that H2B K120 ubiquitination facilitates H3K36me3 activity of Set2.

Auxiliary domains of Set 2 bind nucleosome. Although two Set2 could bind one nucleosome, we did not find a single class with the two Set2 bound. We have, however, observed a cluster of a noisy density on the side of the nucleosome opposite to the bound Set2 SET domain (Fig. 5). Further unfocused classification has enriched for this noisy density generated by the remaining Set2 sequence, which includes several domains and disordered regions (Supplementary Figs. 3d, 9a-b). This less defined parts of Set 2 interact with the Set2 SET domain, unwrapped DNA, ubiquitin and the histone core at multiple sites (Fig. 5). Our data reveal that the auxiliary domains and disordered regions of Set2 bind the nucleosome and ubiquitin, and this prevents binding of the second Set2 to the nucleosome (Fig. 5). 


\section{Discussion}

In conclusion, our data show that Set2 interactions with the $\mathrm{H} 3$ $\alpha \mathrm{N}$ and the H2A C-terminal tail position Set2 on the nucleosome to specifically bind and methylate H3K36. In agreement with our structure, previous work has shown that hydrophobic residues I111, L115, and L116 in the H2A C-terminal tail are required for the H3K36 methylation and repression of cryptic transcription $^{58,59}$. Consistently, mutations in $\mathrm{H} 2 \mathrm{~A}$ residues residues Q114 and N115, that do not bind Set2 in our structure, showed no or little effect on $\mathrm{H} 3 \mathrm{~K} 36 \mathrm{me}^{58}$. Notably, ubiquitination of H2AK119 was shown to inhibit Set2 activity, which is consistent with our structure in which Set2 makes extensive interactions with this part of the $\mathrm{H} 2 \mathrm{~A}$ tail ${ }^{60}$.

Mutational analysis has shown that residues T45, R49, and R52 in $\mathrm{H} 3 \mathrm{aN}$ are required for $\mathrm{H} 3 \mathrm{~K} 36$ methylation and repression of cryptic transcription $58,59,61,62$, in agreement with our structure. Previous work has shown that $\mathrm{H} 4 \mathrm{~K} 44$ is required for Set2 activity ${ }^{58,61}$. Although we do not see direct interaction of H4K44 with the Set2 SET domain, our data show that H4K44 organizes the $\mathrm{H} 2 \mathrm{~A} \mathrm{C}$-terminal tail and the hydrophobic patch that are essential for Set 2 activity.

The Set2:nucleosome complex is further stabilized by the interaction with the DNA, which is consistent with observations that DNA is required for Set2 activity ${ }^{61,63}$. Moreover, in absence of the intact nucleosome Set2 family enzymes show spurious activity toward $\mathrm{H} 3 \mathrm{~K} 4, \mathrm{H} 3 \mathrm{~K} 27, \mathrm{H} 4 \mathrm{~K} 20, \mathrm{H} 4 \mathrm{~K} 44, \mathrm{H} 2 \mathrm{~A}$, and $\mathrm{H} 2 \mathrm{~B}$ residues $^{3,63}$. Our structures explain how interaction with the nucleosome provides the specificity to H3K36 methylation.

Our data show that the Set2 AWS domain interacts with the ubiquitin on $\mathrm{H} 2 \mathrm{BK} 120$, suggesting that ubiquitin helps positioning Set 2 on the nucleosome. This is supported by our biochemical work that shows increased Set 2 tri-methylation activity on H2BK120 ubiquitinated nucleosomes, when compared with the unmodified nucleosomes. Moreover, it is consistent with the in vivo data showing reduced $\mathrm{H} 3 \mathrm{~K} 36 \mathrm{me} 3$ in deletion of the Bre1 E3 ligase ${ }^{43}$, which is required for $\mathrm{H} 2 \mathrm{~B}$ K120 ubiquitination. Previous biochemical and in vivo data also noted the considerable spatial plasticity in the localization of the residue that is ubiquitinated for nucleosome methylation by Dot1 enzyme. Ubiquitin ligated to H2BK120, H2BK125, H2AK22, and fused to H2AS17 stimulated Dot 1 activity $43,57,64$. In agreement, our data show that ubiquitin ligated to $\mathrm{H} 2 \mathrm{BK} 120$ and fused to H2AR19 stimulates Set2 activity. Since ubiquitin is linked to the nucleosome by intrinsically flexible C-terminal tail, it can adopt many positions on the nucleosome. Remarkably, the position of ubiquitin on the nucleosome surface is unique in each of several recently published structures of various factors bound to the H2BK120 ubiquitinated nucleosomes ${ }^{65-67}$ (Supplementary Fig. 9c). This indicates that binding to the interacting partner determines position of the flexible ubiquitin on the nucleosome.

Recently, a structure of H3K36 methyltransferase ASH1L was determined in a complex with its activation partner MRG1568,69. Superposition of the SET domains from ASH1L:MRG15 complexes (PDB ID: 6ago, 6ine) and Set2:NCP complex shows that different interfaces of Set2 bind nucleosome and MRG5 (Supplementary Fig. 9d). This indicates that an activating factor MRG5 can bind Set2 that is bound to the nucleosome to further stimulate its activity.

In our structure we observed a cluster of less defined density that spans from the SET domain and unwrapped DNA to the $\mathrm{H} 2 \mathrm{~A} / \mathrm{H} 2 \mathrm{~B}$ on the opposite side of the nucleosome. Our structure suggest that remaining Set 2 domains and/or disordered density bind the SET domain, ubiquitin, unwrapped DNA, and histone core at multiple sites. This is in agreement with biochemical data showing that full-length Set2 shows higher activity on nucleosomes compared with the isolated SET domain ${ }^{70}$, indicating that auxiliary domains promote and modulate $\mathrm{H} 3 \mathrm{~K} 36$ methylation.

Perturbations in the enzymes that maintain the levels of H3K36 methylation have been reported in many diseases, such as Sotos syndrome, acute myeloid leukemia, multiple myeloma, and prostate cancer. Set 2 enzyme NSD2 is overexpressed in multiple myeloma, bladder, and several other cancers, which correlates with poor prognosis $37,38,71$, making these enzymes potential drug targets. The interaction with the nucleosome we describe in this study could be targeted by small molecules to inhibit Set2 enzymes in treatment of various cancers.

\section{Methods}

Chaetomium thermophilum genomic DNA preparation. Twenty milliliters of saturated C. thermophilum culture were harvested by centrifugation. Cells were resuspended in $0.5 \mathrm{ml}$ of $\mathrm{dH}_{2} \mathrm{O}$ and flash frozen as small droplets in liquid nitrogen. Cells were pulverized under dry ice by mortar and pestle, thawed, and resuspended in extraction buffer $(2 \mathrm{ml}$ of $2 \%$ Triton X-100, $1 \%$ SDS, $100 \mathrm{mM} \mathrm{NaCl}$ $10 \mathrm{mM}$ Tris/HCl, $\mathrm{pH} 8.0,1 \mathrm{mM}$ EDTA). In total, $1.5 \mathrm{ml}$ of phenol:chloroform: isoamyl alcohol (25:24:1) and glass beads were added to pulverized cells. The mixture was vigorously mixed by vortex for $5 \mathrm{~min}$ and aqueous layer was isolated by centrifugation. DNA was precipitated using sodium acetate (final concentration $0.3 \mathrm{M}, \mathrm{pH} 5.2$ ) and 2.5 volumes of ice-cold ethanol, collected by centrifugation and redissolved in TE buffer (10 mM Tris/HCl, $\mathrm{pH} 8.0,1 \mathrm{mM}$ EDTA).

Plasmid construction. Chaetomium thermophilum (source Ed Hurt lab) Set2 was amplified from the genomic DNA and cloned into a pET-Duet plasmid to yield an $\mathrm{N}$-terminally $6 \mathrm{xHis}$-tagged protein followed by a human rhino-virus $3 \mathrm{C}$ protease recognition site. Two intrones contained within the genomic DNA were removed by iPCR ${ }^{72}$. Oligonucleotides used for cloning are listed in Supplementary Table 1. The resulting vector, listed in Supplementary Table 2, was transformed into LOBSTR-BL21(DE3)-RIL (Kerafast) ${ }^{73}$.

Xenopus laevis histone H3K36M and H2BK120C mutant plasmids were generated by iPCR using oligonucleotides listed in Supplementary Table 1. The resulting vector was transformed into BL21(DE3)-pLysS bacterial cell.

Ubiquitin fused to the N-terminus of $\mathrm{H} 2 \mathrm{~A}$ is an efficient mimic of naturally occurring H2BK120 ubiquitination ${ }^{43}$. Gene coding for $S$. cerevisiae ubiquitin was PCR amplified from genomic DNA and cloned into NcoI recognition sequence in the plasmid for $X$. laevis coexpression of soluble $\mathrm{H} 2 \mathrm{~A} / \mathrm{H} 2 \mathrm{~B}$ histone dimer ${ }^{43}$. Restriction enzyme cloning positioned ubiquitin gene between region coding for $6 \mathrm{xHis}-\mathrm{tag}$ and H2A. A short HA tag used for tethering ubiquitin to $\mathrm{H}_{2} \mathrm{~A}^{43}$ was replaced in our construct with an equally long Gly-Ser linker by iPCR. The final plasmid construct contained N-terminal 6xHis-tag followed by thrombin recognition site, ubiquitin and nine residue Gly-Ser linker tethered to H2A R17. Oligonucleotides used are listed in Supplementary Table 1.

Inverse PCR. iPCR reactions were setup in a total volume of $25 \mu \mathrm{l}$. Products were analyzed on the agarose gel and purified using the NucleoSpin Gel and PCR Cleanup kit. Ten microliters of purified PCR product were incubated with $1 \times$ T4 DNA ligase buffer and $5 \mathrm{U}$ of T4 PNK for $1 \mathrm{~h}$ at $37^{\circ} \mathrm{C}$ in a total volume of $20 \mu \mathrm{l}$. T4 DNA ligase $(200 \mathrm{U})$ was added to the reaction and incubated for $1 \mathrm{~h}$ at room temperature. After addition of $10 \mathrm{U}$ of DpnI, the reaction was incubated for $1 \mathrm{~h}$ at $37^{\circ} \mathrm{C}$ and $5 \mu \mathrm{l}$ were transformed into competent XL1-Blue E. coli cells. All obtained plasmid sequences were checked by DNA sequencing.

Set2 expression and purification. E. coli Rosetta (Novagen) bacterial culture, containing vector for Set 2 overexpression, was grown in LB medium containing the appropriate antibiotics and $0.4 \%(\mathrm{w} / \mathrm{v})$ glucose at $37^{\circ} \mathrm{C}$. When the optical density reached 0.6 at $600 \mathrm{~nm}$, the culture was shifted to $18^{\circ} \mathrm{C}$ for $30 \mathrm{~min}$ before it was induced by the addition of $0.2 \mathrm{mM}$ IPTG. After overnight induction at $18^{\circ} \mathrm{C}$, cells were harvested by centrifugation, resuspended in lysis buffer $(50 \mathrm{mM}$ sodiumphosphate, $\mathrm{pH} 8.0,500 \mathrm{mM} \mathrm{NaCl}, 20 \mathrm{mM}$ imidazole, $3 \mathrm{mM} \beta$-mercaptoethanol, 1 $\mathrm{mM}$ phenylmethanesulfonyl fluoride and Benzonase) and lysed using a french press. The cleared supernatant was incubated with Ni Sepharose 6 Fast Flow resin for $30 \mathrm{~min}$ at $4{ }^{\circ} \mathrm{C}$. The resin was extensively washed with lysis buffer in batch and loaded onto a disposable column. On the column, the resin was washed with 4 bed volumes of washing buffer ( $50 \mathrm{mM}$ sodium-phosphate, $\mathrm{pH} 8.0,500 \mathrm{mM} \mathrm{NaCl}, 40$ $\mathrm{mM}$ imidazole, $3 \mathrm{mM} \beta$-mercaptoethanol) and the bound protein was eluted with 4 bed volumes of elution buffer $(50 \mathrm{mM}$ sodium-phosphate, $\mathrm{pH} 8.0,500 \mathrm{mM} \mathrm{NaCl}$, $300 \mathrm{mM}$ imidazole, $3 \mathrm{mM} \beta$-mercaptoethanol). The protein was dialyzed overnight at $4{ }^{\circ} \mathrm{C}$ against $20 \mathrm{mM}$ HEPES/NaOH, pH 7.5, $200 \mathrm{mM} \mathrm{NaCl}, 0.1 \mathrm{mM}$ EDTA, 1 mM DTT. The N-terminal tag was proteolytically removed during dialysis. The protein was further purified on size exclusion Superdex 200 Increase 10/300 equilibrated in $20 \mathrm{mM}$ HEPES/NaOH, pH 7.5, $200 \mathrm{mM} \mathrm{NaCl}, 1 \mathrm{mM}$ DTT. All 
protein purification step were done at $4{ }^{\circ} \mathrm{C}$. The fractions with the protein were concentrated, flash frozen and stored at $-80^{\circ} \mathrm{C}$ as single use aliquots (Supplementary Fig. 1a).

Histone expression and purification. The plasmid for coexpression and copurification of $X$. laevis histone pairs (6xHis_HRV3C_H2A/H2B,6xHis_Ubq_H2A/ H2B, 6xHis_HRV3C_H3/H4) were transformed into E. coli Rosetta cells (Supplementary Table 2). Protein expressions and Ni-NTA purifications were done as described for Set2 methyltransferase enzyme except that all buffers contained $2 \mathrm{M}$ $\mathrm{NaCl}$. After the elution from the resin, the histone pairs were dialyzed overnight at $4{ }^{\circ} \mathrm{C}$ against $25 \mathrm{mM}$ HEPES/ $\mathrm{NaOH}, \mathrm{pH} 7.5,2 \mathrm{M} \mathrm{NaCl}, 0.1 \mathrm{mM}$ EDTA, $1 \mathrm{mM}$ DTT. The samples were further purified via cation-exchange chromatography in batch (SP Sepharose Fast Flow resin). To facilitate binding onto the resin, the samples were diluted with buffer containing $25 \mathrm{mM}$ HEPES/NaOH, pH 7.5 and $1 \mathrm{mM}$ DTT to $500 \mathrm{mM}$ salt concentration. The resin was extensively washed with $500 \mathrm{mM}$ salt buffer in batch and loaded onto a disposable column. On the column, the resin was washed with 2 bed volumes of buffer containing $700 \mathrm{mM}$ salt $(25 \mathrm{mM}$ HEPES/ $\mathrm{NaOH}, \mathrm{pH} 7.5,700 \mathrm{mM} \mathrm{NaCl}$ and $1 \mathrm{mM}$ DTT). The samples were eluted with 4 bed volumes of $25 \mathrm{mM}$ HEPES/NaOH, pH 7.5, $2 \mathrm{M} \mathrm{NaCl}, 1 \mathrm{mM}$ DTT. Histone proteins were concentrated and further purified on the size exclusion Superdex 200 Increase 10/300 GL column equilibrated in $25 \mathrm{mM}$ HEPES/ $\mathrm{NaOH}, \mathrm{pH} 7.5,2 \mathrm{M}$ $\mathrm{NaCl}, 1 \mathrm{mM}$ DTT. The fractions with the protein were analyzed on SDS-PAGE, concetrated and flash frozen.

H3K36M and H3K120C mutants were overexpressed in BL21(DE3) pLysS cell strain and purified from the inclusion bodies ${ }^{74}$. Pelleted cells were resuspended in wash buffer ( $50 \mathrm{mM}$ Tris-HCl, pH 7.5, $100 \mathrm{mM} \mathrm{NaCl}, 1 \mathrm{mM}$ EDTA, 1 mM DTT) and sonicated. After centrifugation for $20 \mathrm{~min}$ at $4{ }^{\circ} \mathrm{C}$ and $17,000 \mathrm{rpm}$ the pellet was resuspended in wash buffer with $1 \%(\mathrm{v} / \mathrm{v})$ Triton X-100, sonicated once more and spun down. The pellet containing inclusion bodies of the corresponding histone protein was washed by completely resuspending it once in buffer with Triton X-100 and twice in buffer without Triton X-100. After each resuspension, the sample was spun for $20 \mathrm{~min}$ at $4{ }^{\circ} \mathrm{C}$ and $17,000 \mathrm{rpm}$. $\mathrm{H} 2 \mathrm{BK} 120 \mathrm{C}$ histone was further purified on cation-exchange chromatography under denaturing conditions. Shortly, the histone protein was disolved in $7 \mathrm{M}$ urea, $50 \mathrm{mM}$ Tris- $\mathrm{Hcl}, 400 \mathrm{mM}$ $\mathrm{NaCl}, 1 \mathrm{mM}$ DTT. Any insoluble components were removed by centrifugation. The protein was bound to cation-exchange column and eluted with the increasing salt gradient. After elution from the ion exchange column, the protein was extensively dialyzed against water, lyophilized and used in cross-linking reaction with ubiquitin. H3K36M was refolded with $\mathrm{H} 4$, also purified from the inclusion bodies, into histone tetramer. Tetramer was further purified under native conditions on ion exchange and size exclusion chromatography using protocol described above for co-expressed soluble histone pairs.

To obtain the histone octamer, we mixed individually purified $\mathrm{H} 2 \mathrm{~A} / \mathrm{H} 2 \mathrm{~B}$ histone dimer (H2A/H2B, Ubq_H2A/H2B or H2A/H2BK120C_Ubq) and (H3/H4) 2 histone tetramer $((\mathrm{H} 3 / \mathrm{H} 4) 2$ or $(\mathrm{H} 3 \mathrm{~K} 36 \mathrm{M} / \mathrm{H} 4) 2)$ in $25 \mathrm{mM} \mathrm{HEPES} / \mathrm{NaOH}$, pH 7.5, $2 \mathrm{M} \mathrm{NaCl}, 1 \mathrm{mM}$ DTT. After an overnight incubation, the histone octamer was purified from the unincorporated components on the size exclusion Superdex 200 Increase 10/300 GL column equilibrated in $25 \mathrm{mM}$ HEPES/ NaOH, pH 7.5, $2 \mathrm{M}$ $\mathrm{NaCl}, 1 \mathrm{mM}$ DTT buffer.

All protein purification steps were done at $+4{ }^{\circ} \mathrm{C}$. The protein samples were analyzed by $17 \%$ SDS-PAGE after each purification step (Supplementary Fig. 1b).

Generation of nonhydrolyzable ubiquitin-H2B histone mimic. The expression plasmid containing a $6 \mathrm{xHis}$-tag at the $\mathrm{N}$-terminus of ubiquitin was a generous gift of Yao $\mathrm{T}^{56}$. Ubiquitin expression was induced in E. coli Rosetta cells with $1 \mathrm{mM}$ IPTG at $37^{\circ} \mathrm{C}$ for $3 \mathrm{~h}$. Cell lysis and Ni-NTA affinity purification under denaturating conditions were performed as described for Set 2 methyltransferase enzyme except that all buffers contained additional $6 \mathrm{M}$ urea. Eluated protein was exhaustively dialyzed against four changes of water before lyophilization.

Lyophilized His6-Ub(G76C) and H2B(K120C) were individually resuspended in $100 \mathrm{mM}$ sodium tetraborate, $\mathrm{pH} 8.5,6 \mathrm{M}$ urea for $1 \mathrm{~h}$ at room temperature. Solubilized proteins were clarified by centrifugation for $20 \mathrm{~min}$ at $17,000 \mathrm{rpm}$ TCEP was added to the protein samples at $10 \mathrm{mM}$ final concentration and incubated at room temperature for $60 \mathrm{~min}$. To remove any free reducing agent, proteins were desalted on PD10 column equlibrated in $50 \mathrm{mM}$ sodium tetraborate, $\mathrm{pH} 8.5,6 \mathrm{M}$ urea. Ubiquitin and H2B-K120C histone, concentrated to $\sim 10 \mathrm{mg} / \mathrm{ml}$, were mixed in molar ratio of 2:1 and cross-linked with 1,3-dichloroacetone in $N, N$ '-dimethylformamide for $60 \mathrm{~min}$ on ice ${ }^{56}$. The reaction was stopped with the addition of $5 \mathrm{mM}$ DTT and incubated for at least $30 \mathrm{~min}$ on ice (Supplementary Fig. 7a).

The cross-linking reaction was dialyzed in Ni-NTA denaturing binding buffer (50 mM sodium-phosphate, $\mathrm{pH} 8.0,500 \mathrm{mM} \mathrm{NaCl}, 6 \mathrm{M}$ urea, $10 \mathrm{mM}$ imidazole, 3 $\mathrm{mM} \beta$-mercaptoethanol) and incubated with Ni Sepharose 6 Fast Flow resin at $4{ }^{\circ} \mathrm{C}$ for $30 \mathrm{~min}$. The resin was extensively washed with the binding buffer and 4 column volumes of the washing buffer with an increased imidazole $(50 \mathrm{mM}$ sodiumphosphate, $\mathrm{pH} 8.0,500 \mathrm{mM} \mathrm{NaCl}, 6 \mathrm{M}$ urea, $20 \mathrm{mM}$ imidazole, $3 \mathrm{mM} \beta$ mercaptoethanol). The proteins (his-tagged ubiquitin, his-tagged ubiquitinubiquitin, his-tagged ubiquitin-H2B) were eluted with the buffer containing 300 $\mathrm{mM}$ imidazole (50 mM sodium-phosphate, $\mathrm{pH} 8.0,500 \mathrm{mM} \mathrm{NaCl}, 6 \mathrm{M}$ urea, 300
$\mathrm{mM}$ imidazole, $3 \mathrm{mM} \beta$-mercaptoethanol). The eluted protein mixture was directly used in the subsequent refolding steps with H2A histone (Supplementary Fig. 7b).

Reconstitution of histone dimers with H2BK120C mimic. H2A histone, for dimer reconstitution, was overexpressed in BL21(DE3) pLysS cell strain and purified from the inclusion bodies ${ }^{74,75}$. To remove minor impurities, H2A histone was further purified on cation-exchange chromatography under denaturating conditions as described. The purified $\mathrm{H} 2 \mathrm{~A}$ was dialyzed thoroughly against at least four changes of distilled water at $4{ }^{\circ} \mathrm{C}$ and lyophilized. Lyophilized protein was resuspended in unfolding buffer (6 M guanidinium hydrochloride, $20 \mathrm{mM}$ Tris, $\mathrm{pH} 7.5$, $1 \mathrm{mM}$ DTT), allowed to unfold for $60 \mathrm{~min}$ at room temperature and spun by centrifugation for $20 \mathrm{~min}$ at $17,000 \mathrm{rpm}$ at $4^{\circ} \mathrm{C}$.

The nickel affinity purification eluate of nonhydrolyzable ubiquitin-histone contains a mixture of ubiquitin-containing species: his-tagged ubiquitin, his-tagged ubiquitin-ubiquitin, and his-tagged ubiguitin-H2B. Thus, the ratio of $\mathrm{H} 2 \mathrm{~A}$ and ubiquitin-H2BK120C histone mimic for dimer reconstitution was estimated by SDS-PAGE and staining with SimplyBlue SafeStain. Histones were mixed at equa molar ratio, dialyzed against two changes of refolding buffer $(25 \mathrm{mM}$ HEPES/ $\mathrm{NaOH}, \mathrm{pH} 7.5,2 \mathrm{M} \mathrm{NaCl}, 1 \mathrm{mM} \mathrm{DTT})$ at $4{ }^{\circ} \mathrm{C}$. Histone dimer was concentrated and further purified on a size exclusion chromatography Superdex 200 Increase 10/ 30 column, pre-equilibrated in buffer containing $15 \mathrm{mM}$ HEPES/ $\mathrm{NaOH}$ pH 7.5, 2 $\mathrm{M} \mathrm{NaCl}, 1 \mathrm{mM}$ DTT. The cleanest fractions were pooled, concentrated and used for histone octamer assembly (Supplementary Fig. 7c-f).

Nucleosome reconstitution. Nucleosomes were reconstituted using the purified octamers and $149 \mathrm{bp}$ DNA fragment containing the 601 nucleosome strong positioning sequence ${ }^{42,48}$. DNA for nucleosome reconstitution was PCR amplified from a plasmid containing the 601 DNA sequence using oligonucleotides listed in Supplementary Table 1. After ethanol precipitation, the DNA was resuspended in $15 \mathrm{mM}$ HEPES-NaOH pH 7.5, $2 \mathrm{M} \mathrm{NaCl}, 1 \mathrm{mM}$ DTT.

The nucleosome reconstitution was done by 'double bag' dialysis method ${ }^{48}$. The dialysis buttons, containing $0.25 \mathrm{ml}$ of histone octamer:DNA mixture, were placed inside a dialysis bag filled with $50 \mathrm{ml} 2 \mathrm{M}$ salt buffer $(15 \mathrm{mM}$ HEPES-NaOH pH 7.5, $2 \mathrm{M} \mathrm{NaCl}, 1 \mathrm{mM}$ DTT). The dialysis bag was dialyzed overnight against $1 \mathrm{l}$ of 1 $\mathrm{M}$ salt buffer (15 mM HEPES-NaOH pH 7.5, $1 \mathrm{M} \mathrm{NaCl}, 1 \mathrm{mM}$ DTT). The next day the dialysis bag was dialyzed for 5-6 h against $1 \mathrm{l}$ buffer containing $15 \mathrm{mM}$ HEPES $\mathrm{NaOH}$ pH 7.5, $50 \mathrm{mM} \mathrm{NaCl}, 1 \mathrm{mM}$ DTT. Finally, only the dialysis buttons were dialyzed for $1 \mathrm{~h}$ in fresh $50 \mathrm{mM}$ salt buffer. All nucleosome reconstitution steps were done at $+4{ }^{\circ} \mathrm{C}$. The reconstitution results were analyzed on $6 \%$ native PAGE run in $1 \mathrm{X}$ TBE buffer at $200 \mathrm{~V}$ in the cold room (Supplementary Fig 1c). The gels were stained with SYBR gold (Thermo Fisher Scientific).

CryoEM grid preparation and data collection. The formation of Set2:NCP complex was monitored by native PAGE (Supplementary Fig. 1d). NCPs and Set2 were incubated for $1 \mathrm{~h}$ on ice in $25 \mathrm{mM}$ HEPES, $\mathrm{pH} 7.5,50 \mathrm{mM} \mathrm{NaCl}, 1 \mathrm{mM}$ DTT, $160 \mu \mathrm{m}$ SAM. Twofold excess of Set over NCPs lead to 50\% shift of the NCP band. At higher, fivefold excess of Set 2 over NCPs we have observed the sample precipitation. Therefore, for cryo-EM sample preparation we have incubated NCPs with twofold excess of Set using identical conditions as for native PAGE analysis Three microliters of the sample $(1-1.2 \mathrm{mg} / \mathrm{ml})$ were applied to freshly glowdischarged Quantifoil R2/1 holey carbon grid. After $3 \mathrm{~s}$ blotting time, grids were plunge-frozen in the liquid ethane using FEI Vitrobot automatic plunge freezer. Humidity in the chamber was kept at $95 \%$.

Electron micrographs were recorded on FEI Titan Krios at $300 \mathrm{kV}$ with a Gatan Summit K2 electron detector ( 3350 micrographs) (Necen, Leiden, Netherlands). Image pixel size was $1.04 \AA$ per pixel on the object scale. Data were collected in a defocus range of 7000-30,000 $\AA$ with a total exposure of $75 \mathrm{e} / \AA^{2}$. Fifty frames were collected and aligned with the Unblur software package using a dose filter ${ }^{76}$.

Several thousand particles were manually picked and carefully cleaned in Relion to remove inconsistent particles. The resulting useful particles were then used for semi-automatic and automatic particle picking in Relion. The contrast transfer function parameters were determined using CTFFIND $4^{77}$. The $2 \mathrm{D}$ class averages were generated with Relion software package ${ }^{78}$. Inconsistent class averages were removed from further data analysis. The $3 \mathrm{D}$ refinements and classifications were subsequently done in Relion. All final refinements were done in Relion using the auto refine option. The initial reference was filtered to $60 \AA$ in Relion. C1 symmetry was applied during refinements for all classes. Particles were split into two datasets and refined independently and the resolution was determined using the 0.143 cutoff (Relion auto refine option). Local resolution was determined with Relion. All maps were filtered to local resolution using Relion with a B-factor determined by Relion.

Molecular models were built using $\operatorname{Coot}^{79}$ and refined in Phenix ${ }^{80}$. Electrostatic surface potential calculation and figure was done using Pymol (The Pymol Molecular Graphics System, Version 2.0 Schrodinger, LCC) ${ }^{81}$. Visualization of all cryo-EM maps was done with Chimera ${ }^{82}$.

Histone methyltransferase assay. In vitro histone methyltransferase assays (HMT) were performed using $0.5 \mu \mathrm{g}$ of recombinantly purified C. thermophilum Set 2 and $2 \mu \mathrm{g}$ of the nucleosomal substrates assembled with $149 \mathrm{bp}$ DNA along 
with $160 \mu \mathrm{m}$ SAM, $25 \mathrm{mM}$ Tris/HCl pH 8.4, $50 \mathrm{mM} \mathrm{NaCl}, 1 \mathrm{mM}$ DTT. For the enzymatic reactions HMT buffer was used in the last dialysis step of the nucleosomes assembly reaction. Set2 enzyme was 20 times diluted in HMT buffer to 0.5 $\mu \mathrm{g} / \mu \mathrm{l}(25 \mathrm{mM}$ Tris/ $\mathrm{HCl} \mathrm{pH} 8.4,50 \mathrm{mM} \mathrm{NaCl}, 1 \mathrm{mM}$ DTT $)$. The reaction was incubated at $40{ }^{\circ} \mathrm{C}$ and at each time point $20 \mu \mathrm{L}$ aliquots were withdraw and the reaction stopped by adding $4 \mathrm{xSDS}$ loading dye. The reaction mixtures were analyzed by SDS-PAGE followed by western blot. Antibodies used include H3K36me1 (ab9048), H3K36me3 (ab9050), H3 (ab1791), and HRP-conjugated anti-rabbit secondary antibody (Biorad, 170-6515). Membrane was incubated with the primary and the secondary antibody for $1 \mathrm{~h}$ at room temperature with the washing steps between each incubation. The signal was visualized with chemoluminescent substrate.

For the H3K36me3 competition assay, the wild-type and H2BK120C ubiquitinated nucleosomes were mixed in one to one ratio and incubated with Set2 enzyme for $1 \mathrm{~h}$ at $40^{\circ} \mathrm{C}$. Four percent of glycerol with bromophenol blue (final volume) was added to the reaction and the samples were loaded onto two native PAGE gels in parallel. Ten percent of the reaction, run on the native PAGE, was stained with SYBRGold. Remaining sample was used to determine the level of the tri-methylation with $\mathrm{H} 3 \mathrm{~K} 36 \mathrm{me} 3$ antibodies.

Reporting summary. Further information on research design is available in the Nature Research Reporting Summary linked to this article.

\section{Data availability}

EM densities have been deposited in the Electron Microscopy Data Bank under accession codes EMD-0559, EMD-20517 and EMD-20516. The coordinates of EM-based models have been deposited in the Protein Data Bank under accession codes PDB 6NZO, 6PX3, and 6 PX1. The source data underlying Fig. 4c-e and Supplementary Figs 1a-f, 7a-fs8a-c are provided as a Source Data file. All other data are available from the corresponding author upon reasonable request.

Received: 15 July 2019 Accepted: 1 August 2019

Published online: 22 August 2019

\section{References}

1. Bowman, G. D. \& Poirier, M. G. Post-translational modifications of histones that influence nucleosome dynamics. Chem. Rev. 115, 2274-2295 (2015).

2. Strahl, B. D. et al. Set2 is a nucleosomal histone H3-selective methyltransferase that mediates transcriptional repression. Mol. Cell. Biol. 22, 1298-1306 (2002).

3. Wagner, E. J. \& Carpenter, P. B. Understanding the language of Lys 36 methylation at histone H3. Nat. Rev. Mol. Cell Biol. 13, 115-126 (2012).

4. Ho, J. W. K. et al. Comparative analysis of metazoan chromatin organization. Nature 512, 449-452 (2014).

5. Weiner, A. et al. High-resolution chromatin dynamics during a yeast stress response. Mol. Cell 58, 371-386 (2015).

6. Kizer, K. O. et al. A novel domain in Set2 mediates RNA polymerase II interaction and couples histone H3 K36 methylation with transcript elongation. Mol. Cell. Biol. 25, 3305-3316 (2005).

7. Li, B., Howe, L., Anderson, S., Yates, J. R. \& Workman, J. L. The Set2 histone methyltransferase functions through the phosphorylated carboxyl-terminal domain of RNA polymerase II. J. Biol. Chem. 278, 8897-8903 (2003).

8. Li, J., Moazed, D. \& Gygi, S. P. Association of the histone methyltransferase Set2 with RNA polymerase II plays a role in transcription elongation. J. Biol. Chem. 277, 49383-49388 (2002).

9. Xiao, T. et al. Phosphorylation of RNA polymerase II CTD regulates $\mathrm{H} 3$ methylation in yeast. Genes Dev. 17, 654-663 (2003).

10. Kim, J. \& Roeder, R. G. Direct Bre1-Pafl complex interactions and RING finger-independent Bre1-Rad6 interactions mediate histone $\mathrm{H} 2 \mathrm{~B}$ ubiquitylation in yeast. J. Biol. Chem. 284, 20582-20592 (2009).

11. Song, Y.-H. \& Ahn, S. H. A Bre1-associated protein, large 1 (Lge1), promotes $\mathrm{H} 2 \mathrm{~B}$ ubiquitylation during the early stages of transcription elongation. J. Biol. Chem. 285, 2361-2367 (2010).

12. Kharchenko, P. V. et al. Comprehensive analysis of the chromatin landscape in Drosophila melanogaster. Nature 471, 480-485 (2011).

13. Keogh, M.-C. et al. Cotranscriptional Set 2 methylation of histone H3 lysine 36 recruits a repressive Rpd3 complex. Cell 123, 593-605 (2005).

14. Joshi, A. A. \& Struhl, K. Eaf3 chromodomain interaction with methylated H3K36 links histone deacetylation to Pol II elongation. Mol. Cell 20, 971-978 (2005).

15. Venkatesh, S., Li, H., Gogol, M. M. \& Workman, J. L. Selective suppression of antisense transcription by Set2-mediated H3K36 methylation. Nat. Commun. 7, 13610 (2016).
16. Carrozza, M. J. et al. Histone $\mathrm{H} 3$ methylation by Set 2 directs deacetylation of coding regions by Rpd3S to suppress spurious intragenic transcription. Cell 123, 581-592 (2005).

17. $\mathrm{Li}, \mathrm{B}$. et al. Histone $\mathrm{H} 3$ lysine 36 dimethylation $(\mathrm{H} 3 \mathrm{~K} 36 \mathrm{me} 2)$ is sufficient to recruit the Rpd3s histone deacetylase complex and to repress spurious transcription. J. Biol. Chem. 284, 7970-7976 (2009).

18. Pai, C.-C. et al. A histone H3K36 chromatin switch coordinates DNA doublestrand break repair pathway choice. Nat. Commun. 5, 4091 (2014).

19. Carvalho, S. et al. SETD2 is required for DNA double-strand break repair and activation of the p53-mediated checkpoint. Elife 3, e02482 (2014).

20. Jha, D. K., Strahl, B. D. \& An, R. N. A. polymerase II-coupled function for histone H3K36 methylation in checkpoint activation and DSB repair. Nat. Commun. 5, 3965 (2014).

21. Guo, R. et al. BS69/ZMYND11 reads and connects histone H3.3 lysine 36 trimethylation-decorated chromatin to regulated pre-mRNA processing. $\mathrm{Mol}$. Cell 56, 298-310 (2014).

22. Luco, R. F. et al. Regulation of alternative splicing by histone modifications. Science 327, 996-1000 (2010).

23. Matsuda, A. et al. Highly condensed chromatins are formed adjacent to subtelomeric and decondensed silent chromatin in fission yeast. Nat. Commun. 6, 7753 (2015).

24. Venkatesh, S. et al. Set 2 methylation of histone H3 lysine 36 suppresses histone exchange on transcribed genes. Nature 489, 452-455 (2012).

25. Smolle, M. et al. Chromatin remodelers Isw1 and Chd1 maintain chromatin structure during transcription by preventing histone exchange. Nat. Struct. Mol. Biol. 19, 884-892 (2012).

26. $\mathrm{Hu}, \mathrm{M}$. et al. Histone $\mathrm{H} 3$ lysine 36 methyltransferase Hypb/Setd2 is required for embryonic vascular remodeling. Proc. Natl Acad. Sci. USA 107, 2956-2961 (2010).

27. McKay, D. J. et al. Interrogating the function of metazoan histones using engineered gene clusters. Dev. Cell 32, 373-386 (2015).

28. Lawrence, M. S. et al. Discovery and saturation analysis of cancer genes across 21 tumour types. Nature 505, 495-501 (2014).

29. Dalgliesh, G. L. et al. Systematic sequencing of renal carcinoma reveals inactivation of histone modifying genes. Nature 463, 360-363 (2010).

30. Wu, G. et al. Somatic histone H3 alterations in pediatric diffuse intrinsic pontine gliomas and non-brainstem glioblastomas. Nat. Genet. 44, 251-253 (2012).

31. Fang, D. et al. The histone H3.3K36M mutation reprograms the epigenome of chondroblastomas. Science 352, 1344-1348 (2016).

32. Behjati, S. et al. Distinct H3F3A and H3F3B driver mutations define chondroblastoma and giant cell tumor of bone. Nat. Genet. 45, 1479-1482 (2013).

33. Lu, C. et al. Histone H3K36 mutations promote sarcomagenesis through altered histone methylation landscape. Science 352, 844-849 (2016).

34. Papillon-Cavanagh, S. et al. Impaired H3K36 methylation defines a subset of head and neck squamous cell carcinomas. Nat. Genet. 49, 180-185 (2017).

35. Klein, B. J. et al. Recognition of cancer mutations in histone H3K36 by epigenetic writers and readers. Epigenetics 13, 683-692 (2018).

36. Weinberg, D. N., Allis, C. D. \& Lu, C. Oncogenic mechanisms of histone H3 mutations. Cold Spring Harb. Perspect. Med. 7, a026443 (2017).

37. Martinez-Garcia, E. et al. The MMSET histone methyl transferase switches global histone methylation and alters gene expression in $t(4 ; 14)$ multiple myeloma cells. Blood 117, 211-220 (2011).

38. Hudlebusch, H. R. et al. The histone methyltransferase and putative oncoprotein MMSET is overexpressed in a large variety of human tumors. Clin. Cancer Res. 17, 2919-2933 (2011).

39. Angrand, P. O. et al. NSD3, a new SET domain-containing gene, maps to 8p12 and is amplified in human breast cancer cell lines. Genomics 74, 79-88 (2001).

40. Skucha, A. et al. MLL-fusion-driven leukemia requires SETD2 to safeguard genomic integrity. Nat. Commun. 9, 1983 (2018).

41. Vlaming, H. et al. Direct screening for chromatin status on DNA barcodes in yeast delineates the regulome of H3K79 methylation by Dot1. Elife 5, e18919 (2016).

42. Bilokapic, S., Strauss, M. \& Halic, M. Histone octamer rearranges to adapt to DNA unwrapping. Nat. Struct. Mol. Biol. 25, 101-108 (2018).

43. Vlaming, H. et al. Flexibility in crosstalk between $\mathrm{H} 2 \mathrm{~B}$ ubiquitination and $\mathrm{H} 3$ methylation in vivo. EMBO Rep. 15, 1077-1084 (2014).

44. Yang, S. et al. Molecular basis for oncohistone H3 recognition by SETD2 methyltransferase. Genes Dev. 30, 1611-1616 (2016).

45. Zhang, Y. et al. Molecular basis for the role of oncogenic histone mutations in modulating H3K36 methylation. Sci. Rep. 7, 43906 (2017).

46. Youdell, M. L. et al. Roles for Ctk1 and Spt6 in regulating the different methylation states of histone H3 lysine 36. Mol. Cell. Biol. 28, 4915-4926 (2008).

47. Fuchs, S. M., Kizer, K. O., Braberg, H., Krogan, N. J. \& Strahl, B. D. RNA polymerase II carboxyl-terminal domain phosphorylation regulates protein 
stability of the Set2 methyltransferase and histone $\mathrm{H} 3$ di- and trimethylation at lysine 36. J. Biol. Chem. 287, 3249-3256 (2012).

48. Bilokapic, S., Strauss, M. \& Halic, M. Structural rearrangements of the histone octamer translocate DNA. Nat. Commun. 9, 1330 (2018).

49. Nelson, C. J., Santos-Rosa, H. \& Kouzarides, T. Proline isomerization of histone $\mathrm{H} 3$ regulates lysine methylation and gene expression. Cell 126, 905-916 (2006).

50. McGinty, R. K. \& Tan, S. Nucleosome structure and function. Chem. Rev. 115, $2255-2273$ (2015)

51. Luo, J. et al. Histone h3 exerts a key function in mitotic checkpoint control. Mol. Cell. Biol. 30, 537-549 (2010).

52. Lee, J.-H. et al. AKT phosphorylates H3-threonine 45 to facilitate termination of gene transcription in response to DNA damage. Nucleic Acids Res. 43, 4505-4516 (2015).

53. Vogler, C. et al. Histone H2A C-terminus regulates chromatin dynamics, remodeling, and histone H1 binding. PLoS Genet. 6, e1001234 (2010).

54. Tolstorukov, M. Y. et al. Histone variant H2A.Bbd is associated with active transcription and mRNA processing in human cells. Mol. Cell 47, 596-607 (2012).

55. Soboleva, T. A. et al. A new link between transcriptional initiation and premRNA splicing: The RNA binding histone variant H2A.B. PLoS Genet. 13, e1006633 (2017).

56. Long, L., Furgason, M. \& Yao, T. Generation of nonhydrolyzable ubiquitinhistone mimics. Methods 70, 134-138 (2014).

57. Chatterjee, C., McGinty, R. K., Fierz, B. \& Muir, T. W. Disulfide-directed histone ubiquitylation reveals plasticity in hDot1L activation. Nat. Chem. Biol. 6, 267-269 (2010).

58. Du, H.-N. \& Briggs, S. D. A nucleosome surface formed by histone H4, H2A, and $\mathrm{H} 3$ residues is needed for proper histone $\mathrm{H} 3 \mathrm{Lys} 36$ methylation, histone acetylation, and repression of cryptic transcription. J. Biol. Chem. 285, 11704-11713 (2010).

59. Endo, H. et al. Nucleosome surface containing nucleosomal DNA entry/exit site regulates H3-K36me3 via association with RNA polymerase II and Set2. Genes Cells 17, 65-81 (2012)

60. Yuan, G. et al. Histone H2A ubiquitination inhibits the enzymatic activity of H3 lysine 36 methyltransferases. J. Biol. Chem. 288, 30832-30842 (2013).

61. Du, H.-N., Fingerman, I. M. \& Briggs, S. D. Histone H3 K36 methylation is mediated by a trans-histone methylation pathway involving an interaction between Set2 and histone H4. Genes Dev. 22, 2786-2798 (2008).

62. Hainer, S. J. \& Martens, J. A. Identification of histone mutants that are defective for transcription-coupled nucleosome occupancy. Mol. Cell. Biol. 31, 3557-3568 (2011)

63. Li, Y. et al. The target of the NSD family of histone lysine methyltransferases depends on the nature of the substrate. J. Biol. Chem. 284, 34283-34295 (2009).

64. McGinty, R. K., Kim, J., Chatterjee, C., Roeder, R. G. \& Muir, T. W. Chemically ubiquitylated histone H2B stimulates hDot1L-mediated intranucleosomal methylation. Nature 453, 812-816 (2008).

65. Anderson, C. J. et al. Structural basis for recognition of ubiquitylated nucleosome by Dot1L methyltransferase. Cell Rep. 26, 1681-1690 (2019).

66. Morgan, M. T. et al. Structural basis for histone H2B deubiquitination by the SAGA DUB module. Science 351, 725-728 (2016).

67. Sundaramoorthy, R. et al. Structure of the chromatin remodelling enzyme Chd1 bound to a ubiquitinylated nucleosome. Elife 7, e35720 (2018).

68. Lee, Y. et al. Structural basis of MRG15-mediated activation of the ASH1L histone methyltransferase by releasing an autoinhibitory loop. Structure $\mathbf{2 7}$, 846-852 (2019).

69. Hou, P. et al. Structural insights into stimulation of Ash1L's H3K36 methyltransferase activity through Mrg15 binding. Structure 27, 837-845 (2019).

70. Wang, Y., Niu, Y. \& Li, B. Balancing acts of SRI and an auto-inhibitory domain specify Set2 function at transcribed chromatin. Nucleic Acids Res. 43, 4881-4892 (2015).

71. Chesi, M. et al. The $t(4 ; 14)$ translocation in myeloma dysregulates both FGFR3 and a novel gene, MMSET, resulting in IgH/MMSET hybrid transcripts. Blood 92, 3025-3034 (1998).

72. Ulrich, A., Andersen, K. R. \& Schwartz, T. U. Exponential megapriming PCR (EMP) cloning-seamless DNA insertion into any target plasmid without sequence constraints. PLoS ONE 7, e53360 (2012).

73. Andersen, K. R., Leksa, N. C. \& Schwartz, T. U. Optimized E. coli expression strain LOBSTR eliminates common contaminants from His-tag purification. Proteins 81, 1857-1861 (2013).
74. Luger, K., Rechsteiner, T. J. \& Richmond, T. J. Expression and purification of recombinant histones and nucleosome reconstitution. Methods Mol. Biol. 119, 1-16 (1999)

75. Luger, K., Rechsteiner, T. J. \& Richmond, T. J. Preparation of nucleosome core particle from recombinant histones. Meth. Enzymol. 304, 3-19 (1999).

76. Grant, T. \& Grigorieff, N. Measuring the optimal exposure for single particle cryo-EM using a $2.6 \AA$ A reconstruction of rotavirus VP6. Elife 4, e06980 (2015).

77. Rohou, A. \& Grigorieff, N. CTFFIND4: Fast and accurate defocus estimation from electron micrographs. J. Struct. Biol. 192, 216-221 (2015).

78. Scheres, S. H. W. RELION: implementation of a Bayesian approach to cryoEM structure determination. J. Struct. Biol. 180, 519-530 (2012).

79. Emsley, P., Lohkamp, B., Scott, W. G. \& Cowtan, K. Features and development of Coot. Acta Crystallogr. D. Biol. Crystallogr. 66, 486-501 (2010).

80. Adams, P. D. et al. PHENIX: a comprehensive Python-based system for macromolecular structure solution. Acta Crystallogr. D. Biol. Crystallogr. 66, 213-221 (2010)

81. Baker, N. A., Sept, D., Joseph, S., Holst, M. J. \& McCammon, J. A. Electrostatics of nanosystems: application to microtubules and the ribosome. Proc. Natl Acad. Sci. USA 98, 10037-10041 (2001).

82. Pettersen, E. F. et al. UCSF Chimera-a visualization system for exploratory research and analysis. J. Comput Chem. 25, 1605-1612 (2004).

83. Robert, X. \& Gouet, P. Deciphering key features in protein structures with the new ENDscript server. Nucleic Acids Res. 42, W320-W324 (2014).

\section{Acknowledgements}

We would like to thank E. Conti and the Cryo EM facility at Max Planck Institute for Biochemistry in Martinsried for access to cryo EM microscope where the grids were screened. We acknowledge NECEN in Leiden for the data collection. The authors would like to thank G. Barucci for genomic DNA preparation, S. Jaklin for excellent technical assistance. This work was supported by St. Jude Children's Research Hospital, the American Lebanese Syrian Associated Charities and ERC-smallRNAhet-309584.

\section{Author contributions}

S.B. and M.H. designed the experiments. S.B. performed biochemical experiments and electron microscopy. S.B and M.H. analyzed the data. S.B. and M.H. wrote the paper.

\section{Additional information}

Supplementary Information accompanies this paper at https://doi.org/10.1038/s41467 019-11726-4.

Competing interests: The authors declare no competing interests.

Reprints and permission information is available online at http://npg.nature.com/ reprintsandpermissions/

Peer review information: Nature Communications thanks the anonymous reviewer(s) for their contribution to the peer review of this work.

Publisher's note: Springer Nature remains neutral with regard to jurisdictional claims in published maps and institutional affiliations.

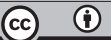

Open Access This article is licensed under a Creative Commons Attribution 4.0 International License, which permits use, sharing, adaptation, distribution and reproduction in any medium or format, as long as you give appropriate credit to the original author(s) and the source, provide a link to the Creative Commons license, and indicate if changes were made. The images or other third party material in this article are included in the article's Creative Commons license, unles indicated otherwise in a credit line to the material. If material is not included in the article's Creative Commons license and your intended use is not permitted by statutory regulation or exceeds the permitted use, you will need to obtain permission directly from the copyright holder. To view a copy of this license, visit http://creativecommons.org/ licenses/by/4.0/.

(C) The Author(s) 2019 